\title{
KONSEP DASAR DAN LANGKAH-LANGKAH PROSES KEPERAWATAN
}

\author{
Cindy Minannisa
}

\section{Cindyminannisa01@gmail.com}

\begin{abstract}
Abstrak
Proses keperawatan adalah suatu metode yang sistematis dan terorganisasi dalam pemberian asuhan keperawatan yang difokuskan pada reaksi dan respons unik dari individu pada suatu kelompok atau perorangan terhadap gangguan kesehatan yang dialami baik secara actual ataupun potensial. Proses keperawatan tidak terlepas dari peran seorang perawat dalam menjalankan tugas dan tanggung jawab dalam memberikan layanan kesehatan tepatnya asuhan keperawatan terhadap pasien. Tujuan: untuk mengetahui konsep dasar dan langkah-langkah dari proses keperawatan kepada klien. Metode: Tugas ini menggunakan metode kualitatif dan analisis dari berbagai jurnal yang berhubungan dengan konsep dasar dan langkah-langkah dari proses keperawatan. Hasil: perawat mengetahui konsep dasar keperawatan dan memahami setiap langkah-langkah dari proses keperawatan dengan baik dan tepat.
\end{abstract}

\section{Kata Kunci: proses keperawatan, konsep dasar, asuhan keperawatan}

\section{Latar Belakang}

Proses keperawatan adalah metode ilmiah yang dipakai dalam memberikan asuhan keperawatan yang professional. Proses keperawatan adalah langkah-langkah sistematis untuk menentukan dan merencanakan penyelesaian masalah klien, lalu mengimplementasikan dan mengevaluasi apakah rencana yang dibuat efektif dalam menyelesaikan masalah yang terjadi (Yura Walsh, 1978).
Asuhan professional dituntut untuk dapat melaksanakan proses keperawatan dengan tepat dan benar. Pemahaman mahasiswa terhadap proses keperawatan sangat penting, karena topic ini akan menjadi bagian yang amat penting dalam melaksanakan asuhan keperawatan.

Menurut Kotler dan Keller (2009), kepuasan pelanggan (customer satisfaction) diartikan sebagi fungsi dari seberapa sesuai harapan pembeli produk dengan kinerja yang dipikirkan pembeli atas produk tersebut. Kualitas pelayanan ditentukan oleh 
manajemen asuhan keperawatan dengan menggunakan metode proses keperawatan untuk menyelesaikan masalah pasien, anatara pasien dan perawat berhubungan secara lansung dalam pengelolaan asuhan keperawatan (Muhlisin, 2008).

Perbedaan asuhan yang professional dengan asuhan tradisional terletak pada penggunaan proses keperawatan. Kemampuan perawat dalam memberi asuhan keperawatan sudah tidak dapat ditawar lagi apabila ia meyakini bahwa asuhannya adalah asuhan yang professional (Rohmah, N dan Walid, S. 2009).

Proses keperawatan mejadi dasar ilmiah perawat dalam melakukan asuhan keperawatan. Pelayanan keperawatan yang diberikan perawat harus memiliki alasan yang rasional dan fakta ilmiah. Agar pelayanan keperawatan yang diberikan sesuai dan tepat sasaran. Selain itu pelayanan keperawatan tentu memerlukan proses keperawatan. Ini menunjukkan seberapa besar manfaat proses keperawatan terhadap layanan atau asuhan keperawatan yang dilakukan oleh perawat.

Bentuk kualitas pelayanan perawat dalam melakukan tindakan yaitu rasa kepuasan pasien terhadap pelayanan yang perawat betikan kepada pasien. Pelayanan keperawatan ini akan memuaskan pasien dengan penerapan asuhan keperawatan professional, kepuasan pasien ditentukan salah satunya dengan pelayanan keperawatan yang optimal (Fisbach, 1991).

Begitu juga dengan pelayanan yang kita berikan kurang memuaskan dan tidak tepat sehingga memberikan pengaruh negative terhadapa pasien yang menyebabkan pasien tidak puas dengan pelayanan yang kita berikan. Apabila tanggung jawab atau peran dari perawat baik dalam hal dokumentasi supervise dan sentralisasi obat tidak dijalankan dengan baik yang menunjukkan kinerja perawat menurun (Azwar, 1996).

Dalam pemenuhan asuhan keperawatan terdapat beberapa langkahlangkah dari proses keperawatan yang harus dijalankan. Setiap langkah dari proses keperawatan ini salang terkai dan ketergantungan satu sama lain. Jika dari proses keperawatan ini langkah-langkahnya tidak dilaksanakan secara keseluruhan maka proses keperawatan tidak akan berjalan dengan baik. Karena jika satu saja langkah itu tidak dilaksanakan ataupun tidak berjalan baik maka akan mempengaruhi tahap yang lain dan asuhan keperawatan yang dihasilkan atau diberikanpun tidak akan 
sempurna, dan klien akan merasakan ketidak puasan terhadap asuhan atau pelayanan keperawatan.

Pelaksanaan proses keperawatan merupakan alat atau cara perawat dalam melaksanakan tugas, wewenang dan tanggung jawab yang diemban seorang perawat. Sebagai seorang perawat proses keperawatan dapat digunakan sebagai pedoman dalam pemecahan masalh, dapat mewujudkan profesi yang memiliki professional yang tinggi, serta dapat memberikan kebebasan kepada klien untuk mendapatkan pelayanan yang cukup sesuai dengan kebutuhannya, sehingga dapat dirasakan manfaat baik perawat ataupun klien.

\section{Metode}

Metode ini menggunakan metode kualitatif analisis berlandaskan teori dari buku, jurnal, e-book ataupun sumber informasi lainnya yang memuat informasi dengan pembahasan konsep dasar dan langkah-langkah dari proses keperawatan. Dengan metode ini informasi pembahasan mengenai konsep dasar dan langkah-langkah dari proses keperawatan bagi seorang perawat dapat memahami dan mempelajari bagaimana cara menlaksanakan asuhan keperawatan dengan tepat sesuai dengan langkah-langkah proses keperawatan.

\section{Hasil}

Proses keperawatan adalah suatu pendekatan untuk pemecahan masalah yang memampukan perawat untuk mengatur dan memberikan asuhan keperawatan. Proses keperawatan mengandung elemen berpikir kritis yang memungkinkan perawat membuat penilaian dan melakukan tindakan berdasarkan nalar.

Dalam mencapai kuaitas asuhan keperawatan yang baik, perawat harus mampu melakukan proses keperawatan yang baik dan benar. Dimana proses keperawatan merupakan sumbangan yang diberikan perawat melalui pelaksanaan proses keperawatan.

Proses keperawatan yang didasari teori Orlando Deliberative Nursing Process menyatakan bahwa tindakan atau perilaku yang ditunjukkan perawat merupakan hasil pertimbangan berdasarkan kebutuhan pasien. Hal tersebut berarti bahwa perawat profesional melakukan eksplorasi kebutuhan dan masalah atau gangguan kebutuhan yang terjadi pada pasien dengan menggunakan persepsi, proses berpikir kritis, penalaran 
klinis, dan atau perasaan perawat yang berhubungan dengan kebutuhan dasar pasien. Proses keperawatan membantu perawat mendapatkan luaran, mengukur kualitas pelaksanaan asuhan keperawatan dan memudahkan perawat untuk melakukan praktik klinis keperawatan khususnya bagi perawat pemula (Xiao et al., 2017).

Proses keperawatan merupakan gambaran dari hubungan antara pasien dan perawat, identitas dan peran profesionalitas perawat, dan pengembangan pengetahuan perawat. Antusiasme perawat dalam menerima tantangan baru dalam memberikan pelayanan telenursing sangat tinggi, hal tersebut dapat berdampak pada kemampuan meningkatkan komunikasi yang efektif antara perawat dan pasien (Padila et al., 2018).

Hubungan antara pasien dan perawat merupakan interaksi timbal balik dimana respon pasien dan perawat saling memengaruhi dan terus berkembang sejalan dengan perubahan respon antara pasien dan perawat. Salah satu fungsi profesionalitas perawat adalah menemukan kebutuhan pasien yang tidak terpenuhi dan kemudian memberikan bantuan untuk memenuhi kebutuhan tersebut.
Proses keperawatan memfasilitasi perawat untuk berkembang sebagai seorang pemikir yang logis untuk menghasilkan peningkatan respon dan perilaku pasien dalam pemenuhan kebutuhannya serta pentingnya partisipasi pasien dalam keseluruhan proses (Stonehouse, 2017).

Kualitas pelayanan keperawatan di rumah sakit tidak akan berjalan dengan baik apabila proses keperawatan yang dilaksanakan tidak terstruktur dengan baik. Proses keperawatan terdiri dari lima tahapan, yaitu pengkajian, diagnosis, perencanaan, implementasi, dan evaluasi.

Deswani (2009), kegiatan-kegiatan yang dilakukan pada setiap tahap dari proses keperawatan ialah pada tahap pengkajian kegiatan yang dilakukan adalah mengumpulkan data seperti riwayat keperawatan, pemeriksaan fisik, dan pemeriksaan data sekunder lainnya. Setelah data didapatkan masuk ketahap diagnosis dimana diagnosis keperawatan merupakan sebuah konsep kritis untuk memandu proses pengkajian dan intervensi (Rabelo et al., 2016). Diagnosis juga menjadi komunikasi dan basis ilmu keperawatan dalam interaksinya dengan disiplin ilmu lain.

Tahap selanjutnya adalah tahap perencanaan, dimana pada tahap ini 
menyusun prioritas masalah, merumuskan tujuan dan kriteria hasil, memilih strategi asuhan keperawatan, melakukan konsultasi dengan tenaga kesehatan lainnya dan mendokumentasikan rencana keperawatan. Tahap implementasi adalah tahap melakukan rencana yang telah dibuat pada klien. Tahap akhir dari proses keperawatan adalah evaluasi, dimana pada tahap ini kegiatan yang dilakukan adalah membandingkan respons klien dengan kriteria hasil dan mengkaji respons klien setelah dilakukan intervensi keperawatan.

Oleh sebab itu, hasil dari artikel ini adalah perawat dapat memahami konsep dasar dan langkah-langkah dari proses keperawatan untuk memberi dan melaksanakan asuhan keperawatan yang baik dan tepat.

\section{Pembahasan}

Proses keperawatan adalah aktivitas yang mempunyai maksud yaitu praktik keperawatan yang dilakukan dengan cara sistematik. Selama melaksanakan proses keperawatan, perawat menggunakan dasar pengetahuan yang komprehensif untuk mengkaji status kesehatan pasien, menciptakan penilaian yang tepat, mendiagnosa, dan mengidentifikasi hasil akhir kesehatan klien. Selain itu juga merencanakan, menerapkan dan mengevaluasi tindakan keperawatan yang tepat untukmencapai hasil akhir tersebut (Dermawan, 2012).

Dalam mencapai kuaitas asuhan keperawatan yang baik, perawat harus mampu melakukan proses keperawatan yang baik dan benar. Dimana proses keperawatan merupakan sumbangan yang diberikan perawat melalui pelaksanaan proses keperawatan. Proses keperawatan merupakan kerangka pikir yang digunakan oleh seorang perawat untuk melaksanakan fungsi dan tanggung jawabnya secara mandiri. Dalam melakukan proses keperawatan, tahap pertama yakni melakukan (Hidayat, 2002).

Proses keperawatan adalah serangkaian tindakan yang sistematis berkesinambungan meliputi tindakan untuk mengidentifikasi masalah kesehatan individu atau kelompok baik yang aktual maupun potensial kemudian merencanakan tindakan untuk menyelesaikan, mengurangi, atau mencegah terjadinya masalah baru dan melaksanakan tindakan atau menugaskan orang lain untuk melaksanakan tindakan keperawatan serta mengevaluasi keberhasilan dari tindakan yang dikerjakan (Rohmah, N dan Walid, S. 2009). 
Jadi inti dari proses keperawatan adalah suatu cara atau metode yang sistematis dalam memberikan asuhan keperawatan yang dilakukan oleh perawat dan bekerjasama dengan pasien (induvidu, keluarga, masyarakat) yang bertujuan untuk mengidentifikasi masalah keperawatan dengan melakukan pengkajian, menentukan diagnosa, merencanakan tindakan yang akan dilakukan, melaksanakan tindakan serta mengevaluasi hasil asuhan keperawatan yang telah diberikan dengan berfokus pada pasien, berorientasi pada tujuan yang telah ditetapkan bersama.

Hubungan antara pasien dan perawat merupakan interaksi timbal balik dimana respon pasien dan perawat saling memengaruhi dan terus berkembang sejalan dengan perubahan respon antara pasien dan perawat. Salah satu fungsi profesionalitas perawat adalah menemukan kebutuhan pasien yang tidak terpenuhi dan kemudian memberikan bantuan untuk memenuhi kebutuhan tersebut. Proses keperawatan memfasilitasi perawat untuk berkembang sebagai seorang pemikir yang logis untuk menghasilkan peningkatan respon dan perilaku pasien dalam pemenuhan kebutuhannya serta pentingnya partisipasi pasien dalam keseluruhan proses (Stonehouse, 2017).
Proses keperawatan merupakan inti dan esensi keperawatan dalam memberikan tindakan keperawatan yang dapat digunakan pada setiap setting pelayanan sehingga mampu menghasilkan asuhan keperawatan yang tepat khususnya kepada keluarga. Proses keperawatan merupakan suatu bentuk pendekatan dalam memecahkan masalah yang mendukung kemampuan perawat dalam mengatur dan memberikan asuhan keperawatan. Pelaksanaan proses keperawatan seharusnya dipikirkan secara kritis agar memungkinkan perawat dalam melakukan melakukan tindakan dan penilaian berdasarkan penalaran. Salah satu hal terpenting dari keperawatan yaitu pemberian asuhan keperawatan pada pasien atau individu.

Perawat saat bertemu dengan klien baik klien sebagai individu maupun keluarga tentunya akan memicu terjadinya interaksi baik berupa komunikasi, observasi, dukungan, pendidikan kesehatan, ataupun saat melaksanakan tindakan asuhan keperawatan. Perawat mendukung dan memotivasi individu dan keluarga dalam mempertahankan dan meningkatkan kesehatannya. Perawat memberi asuhan kepada klien dengan mengkombinasikan metode penyelesaian masalah secara ilmiah 
dengan keterampilan untuk memberi asuhan keperawatan melalui proses keperawatan.

Asuhan professional dituntut untuk dapat melaksanakan proses keperawatan dengan tepat dan benar. Pemahaman perawat terhadap proses keperawatan sangat penting, karena menjadi satu hal utama dalam melaksanakan asuhan keperawatan. Proses keperawatan akan membedakan asuhan keperawatan professional dengan asuhan keperawatan tradisional. Kemampuan untuk menerapkan proses keperawatan tidak dapat ditawar-tawat lagi (Rohmah \& Walid, 2009).

Dalam pelayanan asuhan keperawatan, proses keperawatan itu dari tahun ke tahun mengalami perkembangan yang sangat pesat. Sejarah perkembangan keperawatan sebagai profesi ditinjau dari perkembangan keperawatan dunia dan perkembangan keperawatan Indonesia (Hidayat, 2008). Seiring dengan perkembangan keperawatan, sebagai penemuan dalam dunia keperawatan juga diperkenalkan salah satunya proses keperawatan.

Tujuan umum dari proses keperawatan adalah peningkatan kualitas asuhan keperawatan. Adanya proses keperawatan akan menciptakan pelayanan asuhan keperawatan yang berkualitas dengan indikator teratasinya semua masalah yang terkait dengan kebutuhan dasar manusianya klien. Adapun tujuan khususnya dalah sebagai berikut.

1. Teridentifikasinya masalah-masalah terkait kebutuhan dasar manusianya klien.

2. Dapat menentukan diagnosa keperawatan.

3. Tersusunnya perencanaan keperawatan yang tepat untuk mengatasi diagnosa keperawatan.

4. Terlaksananya tindakan-tindakan keperawatan secara tepat dan terencana.

5. Diketahuinya perkembangan klien.

6. Dapat ditentukannya tingkat keberhasilan asuhan keperawatan.

Sifat proses keperawatan adalah sebagai berikut:

- Terbuka dan fleksibel

- Dilakukan melalui pendekatan individual

- Penanganan masalah yang terencana

- Mempunyai arah dan tujuan

- Merupakan siklus yang saling berhubungan 
- Terdapat validasi data dan pembuktian masalah

Langkah-langkah pada proses keperawatan adalah mengumpulkan informasi, menentukan diagnosa keperawatan actual dan potensial, mengidentifikasi hasil yang dapat diukur dan menggambarkan respon pasien, mengembangkan intervensi individu yang bertujuan mencapai hasil, mengevaluasi kemajuan pencapaian tujuan, menilai rencana keperawatan didasarkan pada penggunaan proses keperawatan (Hudak dan Gallo, 1997).

Berdasarkan pendapat dari beberapa ahli tentang tahapan dalam proses keperawatan, tahn dimulai dengan: tahap pengkajian, tahap diagnosa keperawatan, tahap perencanaan, tahap pelaksanaan serta tahap evaluasi. Setiap tahapan terdapat beberapa kegiatan atau langkah-langkah harus ditempuh, yaitu:

1. PROSES PENGKAJIAN DALAM ASUAH KEPERAWATAN

Pengkajian keperawatan adalah tahap awal dari proses keperawatan dan merupakan suatu proses yang sistematis dalam pengumpulan data dari berbagai sumber data untuk mengevaluasi dan mengidentifikasi status kesehatan
klien.Pengkajian keperawatan merupakan dasar pemikiran dalam memberikan asuhan keperawatan sesuai dengan kebutuhan klien. Pengkajian yang lengkap, dan sistematis sesuai dengan fakta atau kondisi yang ada pada klien sangat penting untuk merumuskan suatu diagnosa keperawatan dan dalam memberikan asuhan keperawatan sesuai dengan respon individu.

- Pengumpulan Data

- Sumber Data Keperawatan

- Teknik Pengumpulan Data Keperawatan

- Anamnesis

- Observasi

- Pemeriksaan Fisik

2. DIAGNOSA KEPERAWATAN

Diagnosa keperawatan merupakan suatu pertanyaan yang menggambarkan respons manusia (keadaan sehat atau perubahan pola interaksi actual/potensial ) dari individu atau kelompok.Diagnosa keperawatan merupakan penilaian klinis tentang respons individu, keluarga, atau komunitas terhadap masalah kesehatan atau proses kehidupan actual ataupun potensial sebagai dasar pemilihan intervensi keperawatan untuk mencapai hasil tempat perawat bertanggung jawab.

Tujuan diagnosis keperwatan adalah memungkinkan Anda sebagai perawat untuk 
menganalisis dan mensintesis data yang telah dikelompokkan, selain itu diagnosis keperawatan digunakan untuk mengidentifikasi masalah, factor penyebab masalah, dan kemampuan klien untuk dapat mencegah atau memecahkan masalah.

Diagnosis keperawatan didapatkan oleh perawat dengan melakukan penelitian yang melibatkan pasien dan keluarga. Penentuan diagnosis pasien bermanfaat untuk memvalidasi, memperkuat dan menentukan prioritas masalah pasien dengan benar. Sesuai dengan UU No. 38 Tahun 2014, perawat berwenang untuk menegakkan diagnosis keperawatan dalam proses menjalankan tugas sebagai pemberi asuhan keperawatan.

Pertimbangan diagnosis adalah proses penggunaan data pengkajian klien yang sudah dikumpulkan untuk menjelaskan secara legal keputusan klinis. Proses diagnosis berawal dari proses pengkajian dan termasuk defenisi dan memilih dengan cepat diagnosis yang berhubungan.

Langkah-langkah dalam menentukan diagnosa keperawatan adalah :

1) Melakukan klasifikasi data

2) Membuat Interpretasi Data

3) Menentukan Hubungan Sebab Akibat

4) Merumuskan

Diagnosis

Keperawatan

\section{RENCANA KEPERAWATAN}

Materi yang akan di bahas dalam rencanaintervensi keperawatan ini terdiri dari: pengertian rencana keperawatan, tujuan rencana keperawatan, kegiatan dalam diagnosis keperawatan, prioritas masalah keperawatan, tujuan dan criteria hasil, Rencana keperawatan, Rasional rencana keperawatan, Dokumentasi rencana keperawatan. Perencanaan adalah pengembangan strategi desain untuk mencegah, mengurangi, dan mengatasi masalah-masalah yang telah diidentifikasi dalam diagnosis keperawatan. Desain perencanaan menggambarkan sejauh mana perawat mampu menetapkan cara menyelesaikan masalah dengan efektif dan efisien.

4. RENCANA ATAU KEPERAWATAN

Pelaksanaan adalah realisasi rencana tindakan untuk mencapai tujuan yang telah Anda tetapkan. Kegiatan dalam pelaksanaan juga meliputi pengumpulan data berkelanjutan, mengobservasi respon klien selama dan sesudah pelaksaan tindakan, serta menilai data yang baru. Faktor-faktor 
yang mempengaruhi pelaksanaan keperawatan antara lain:

- Kemampuan intelektual, teknikal, dan interpersonal.

- Kemampuan menilai data baru.

- Kreativitas dan inovasi dalam membuat modifikasi rencana tindakan.

- Penyesuaian selama berinteraksi dengan klien.

- Kemampuan mengambil keputusan dalam memodifikasi pelaksanaan.

- Kemampuan untuk menjamin kenyamanan dan keamanan serta efektivitas tindakan.

Tahap - tahap dalam pelaksanaan tindakan keperawatan antara lain :

- Tahap persiapan

- Tahap pelaksanaan

- Tahap sesudah pelaksanaan

\section{EVALUASI KEPERAWATAN}

Evaluasi keperawatan adalah penilaian dengan cara membandingkan perubahan keadaan pasien (hasil yang diamati) dengan tujuan dan kriteria hasil yang perawat buat pada tahap perencanaan. Tujuan dari evaluasi antara lain: mengakhiri rencana tindakan keperawatan, memodifikasi rencana tindakan keperawatan serta meneruskan rencana tindakan keperawatan.

Evaluasi dilakukan secara berkesinambungan dengan melibatkan klien dan tenaga kesehatan lainnya. Secara umum evaluasi ditujuankan untuk:

- Melihat dan menilai kemampuan klien dalam mencapai tujuan

- Mengkaji penyebab jika tujuan asuhan keperawatan belum tercapai (Asmadi, 2008).

\section{Penutup}

Proses keperawatan dideskripsikan sebagai cara berpikir khusus mengenai cara merawat klien, baik klien sebagai individu maupun klien sebagai keluarga. Proses keperawatan merupakan suatu metode sistematis yang mengarah pada hubungan perawat dan klien saat menentukan, merencanakan, mengimplementasikan asuhan keperawatan dan mengevaluasi hasil asuhan keperawatan yang diberikan dalam membantu individu memenuhi kebutuhan dasar dan kebutuhan tingkat tertinggi klien. hal ini memerlukan peran serta keluarga agar asuhan keperawatan yang diberikan dapat tercapai secara optimal.

Untuk menilai kualitas pelayanan keperawatan diperlukan adanya standar praktik keperawatan yang merupakan pedoman bagi perawat dalam melaksanakan 
asuhan keperawatan yang diwujudkan dalam bentuk proses keperawatan baik dari pengkajian sampai evaluasi (Nursalam, 2008).

Proses keperawatan terdiri dari 5 langkah-langkah yang harus dilaksanakan yaitu: Pengkajian, diagnosis, perencanaan, implementasi dan evaluasi. Dimana setiap langkah-langkah tersebut harus dilaksanakan karena setiap tahap atau langkah dari proses keperawata itu saling terkait dan tergantung satu-sama lain. Untuk menjalankan semua tahapan ini, seorang perawat harus memiliki keterampilan dan pengetahuan yang cukup agar bisa mengatasi dan menghadapi masalah masakah klien dan dapat mengambil keputusan yang tepat dan benar.

\section{Daftar Pustaka}

Ana Triwijayanti, R. R. (2020). GAMBARAN PSIKOLOGIS KEPUASAN KELUARGA DALAM MENERIMA ASUHAN

KEPERAWATAN. Jurnal Ilmu Keperawatan Jiwa, 3(1), 75-82.

Angganis F, A. dkk. (2012). Hubungan Sikap Perawat Dengan Pendokumentasian Asuhan Keperawatan di Ruang Rawat Inap
Umum Rs. Dr Sitanala di Tangerang. Jurnal keperawatan, 1, 12.

Budiono. 2016. Modul Bahan Ajar Cetak Keperawatan Konsep Dasar Keperawatan. Jakarta: Bumi Medika Kementrian Kesehatan Republik Indonesia.

Dheni Koerniawan, N. E. (2020, Juni). APLIKASI STANDAR PROSES KEPERAWATAN: DIAGNOSIS, OUTCOME,DAN INTERVENSI PADA ASUHAN

KEPERAWATAN. Jurnal Keperawatan Silampari, 3(2), 739751.

Dhian W. 2012. Hubungan Kelengkapan Dokumentasi Keperawatan dengan Mutu Pelayanan Keperawatan di Ruang Melati RSUD Prof. Margono Soekarjo Purwokerto. Skripsi. Tidak Diterbitkan. Fakultas Ilmu Kesehatan. Universitas Muhammadiyah Purwokerto.

Fatimah. 2017. Penerapan Model Pendokumentasian Asuhan Keperawatan pada Ruang Rinra Sayang II di RSUD Haji Makasar. Skripsi. Tidak Diterbitkan. Fakultas 
Kedokteran dan Ilmu Kesehatan. Universitas Islam Negeri Alauddin.

Maria Terok, dkk. 2015. Hubungan Kinerja Pelaksana dengan Penerapan Proses Keperawatan di Irina C RSU Prof. Dr. D. Kandau Manado

Miladiyah, N., Mustikasari, Dewi. G. (2015). Hubungan Motivasi dan Komitmen Organisasi dengan Kinerja Perawat dalam Pelaksanaan Dokumentasi Asuhan Keperawatan. Jurnal Keperawatan Indonesia, 18(1), 9-16

Mohamad Kasim, M. A. (2016, Mei). PENINGKATAN KUALITAS PELAYANAN DAN PENDOKUMENTASIAN ASUHAN KEPERAWATAN DENGAN METODE TIM. NurseLine Journal, 1(1), 62-72.

Mohammad Iqbal Bumulo, H. B. (2017, Agustus). PENGARUH MANAJEMEN MODEL ASUHAN KEPERAWATAN PROFESIONAL TIM TERHADAP KUALITAS PELAYANAN KEPERAWATAN DI BANGSAL PRIA RSUD DATOE BINANGKANG KABUPATEN BOLAANG
MONGONDOW. e-Jurnal

Keperawatan (e-Kp), 5(2), 1-6.

Novieastari, E. (2013). Diagnosis Keperawatan Sejahtera. Jurnal Keperawatan Indonesia, 7(2) , 7788.

Nurjannah I. (2017, Maret). Perbandingan Antara Diagnostis Yang Sering Digunakan Dengan Possible Diagnosis Yang Diprediksikan Oleh Perawat Pada Klien Dengan Gangguan Jiwa. Jurnal Keperawatan Klinis dan Komunitas, 1(1).

Prema R. 2018. Kompetensi Perawat dalam Merumuskan Diagnosa Keperawatan pada Pasien di Ruang Rawat Inap RSUD Tugurejo Semarang. Manuskrip. Tidak Diterbitkan. Fakultas Ilmu Keperawatan dan Kesehatan. Universitas Muhammadiyah Semarang.

Rutami. (2012). Pelaksananan Proses Pengkajian Keperawatan di Ruang Rawat Inap RSUP.H Adam Malik Medan. Medan : Universitas Sumatera Utara.

Simamora, R. H. (2019). Development of Guidelines for Applying appropriate Patient Identification to Achieve 
Patient Safety Goal INC2019 12th International Nursing Conference. $2019.10455 \quad$ - $455 \quad$ (1 pages) UCI(KEPA) : I410-ECN-0101-2019512-001224337

Simamora. R. H. (2008) The correlation of ward chief's giving direction and command and the performance of on-duty nurses at Jember dr. Subandi general hospital inpatient wards. jurnal Administrasi dan Kebijakan Kesehatan,

(https://fkm.unair.ac.id/jurnaladministr)

Supratti, A. (2016, Juli). PENDOKUMENTASIAN STANDAR ASUHAN KEPERAWATAN DI RUMAH SAKIT UMUM DAERAH MAMUJU, INDONESIA. Jurnal Kesehatan MANARANG, 2(1), 4451. 2017 